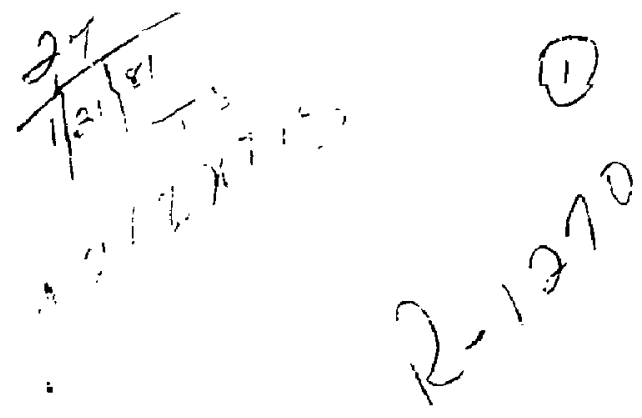

I (II)- 18882

NOVETTE CHAIN OESIGH ANO PERFORMANCE

John T. Hunt, D. Kalph Speck

Decemter 11,1980

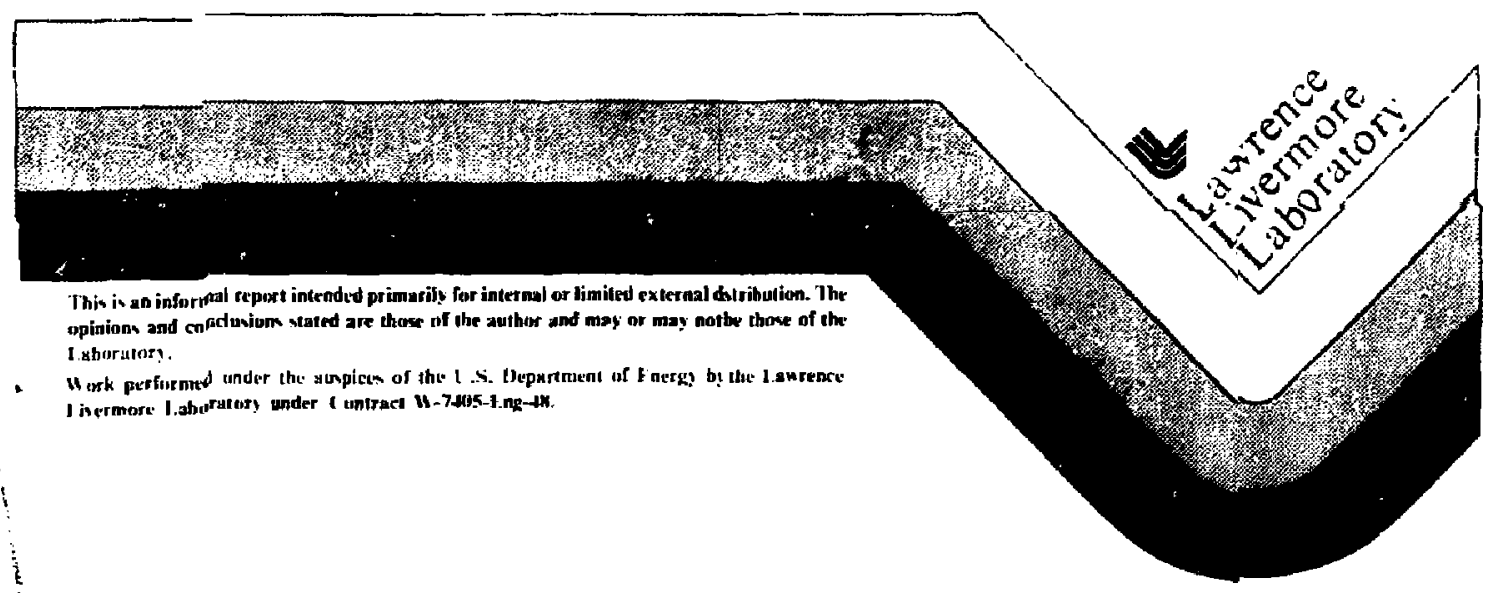




\section{NOVETTE CHAIN DESIGN AND PERFORMANCE}

John T. Hunt, D. Ralph Speck

December 11, 1980

University of California

Lawrence Livermure National Labcratcry

P.0. Box 5508

Livermore, CA 94550

\section{OVERVIEW}

Novette is a two beam, twin wavelength (1.05 microns, and 0.53 microns) target irradiation facility whose projected performance at both wavelengths exceeds the 20 beam Shiva system. The system is readily upgradable to 0.35 microns target irradiation capability by adding a second KDP crystal array to each of its two arms and changing the optical elements between the second crystal and the target. Multiple wavelenoth operation and the large aperture of Novette will require an advanced target focusing system. Several options are under consideration including an $f / 1.5$ axicon system. Listed below is the technical baseline for the system and its profected oerformance:

Tarqet Irradiating Wavelenath: $1.05 \mu \mathrm{m} ; 0.53 \mu \mathrm{m}$

Final Amplifier Aperture: $\quad 46 \mathrm{~cm}$

Finat Beam Aperture: $\quad 74 \mathrm{~cm}$

Focusing Onrics: Init.al activation $f / ?$ Nowa bean fizm stic lenses

Later an advanced $\mathrm{f} / 1.5$ systs

Frequency Conversion Crystais: $74 \mathrm{~cm}$ clear aperture, $18 \mathrm{~mm}$ thick, one $5 \times 5$ monotitic array of $15 \mathrm{~cm} \times 15 \mathrm{~cm}$ elements and one $3 \times 3$ monolithic array of $26 \mathrm{~cm} \times 26 \mathrm{~cm}$ elements

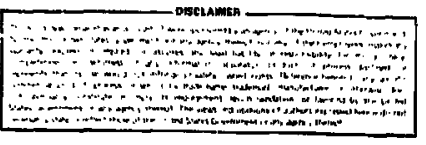


Pulse Length:

Energy Per Arm:

Design Fluence:

Power Conditioning:

Laser Glass:

Target Shots Start: NOVETTE DESIGN CONSIDERATIONS
$100 \mathrm{ps}$ to $5 \mathrm{~ns}$

$10-15 \mathrm{~kJ}(1.05 \mu \mathrm{m})$

$7-10 \mathrm{~kJ}(0.52 \mu \mathrm{m})$

Per Nova

Per Nova

Phosphate

July, 1982

\section{Staging}

The Novette laser system consists of two Nova phosphate glass laser chains. Figure 1 shows an optical schematic of the Novette/Nova chain. This chain consists of a driver section. which terminates at $208 \mathrm{~mm}$ amplifier aperture, followed by $3.15 \mathrm{~mm}$ and $460 \mathrm{~mm}$ diameter clear aperture output emplifier stages. The driver section contains primarily Shiva hardware with the amplifiers retrofitted with phosphate glass. The high energy needed to drive the larger Nova amplifiers requires the addition of two $208 \mathrm{~mm}$ "box" amplifiers to the Shiva driver chain. The $315 \mathrm{~mm}$ and $460 \mathrm{~mm}$ aperture output amplifiers are of box qeometry each containing two disks. There will be total of 8 disks in the $315 \mathrm{~mm}$ stage and 6 disks in the $460 \mathrm{~mm}$ stage. Space is provided such that one additional anplifier at each diameter could he adjed should a future upgrade be desirable. Following the las amplifier stage the beam will be expanded to $740 \mathrm{~mm}$ diameter. Two mirrors are required in one arm and three mirrors in the other to direct the output heam through the Potassiun Di Hydrogen Pliosphate (KDP) doubling crystals to the target focusing optics.

The Nova chains require: single fold at the output of the $208 \mathrm{~mm} / 315 \mathrm{~mm}$ spatial filter. The length of the 381 High Bay buiding requires that the Novette chain $h$, re an additional fold at the output of the $91.7 \mathrm{~mm} / 150$ mon spatial fllter. Both chains will be driven by a common oscillator/preamplifier section as in Shiva. Present plans are to terminate the oscillator/ preamplifier with $50 \mathrm{~mm}$ diameter rods to provide a nominal output energy of 10 joules. The 
master 0scillators and the preamplifier stages will be housed in a side lab of the 381 High Bay. The beam will be transported into the main laser bay from this side lab with a spatial filter relay element.

The Novette chains wil' be spatially filtered and fully relayed The object plane of the relay will be a hard aperture placed at the entrance to each chain with successive image planes occurring near the input lens of each spatial filter/relay element and beyond the first turning mirror in the target bay. Table 1 sumarizes the spatial filter parameters for the Novette baseline chain. The pinhole diameters are chosen so that the beam intensity un the pinhole edges does not exceed $10^{11}$ $\mathrm{W} / \mathrm{cm}^{2}$ for nominal 10 terawatt per chain, $1 \mathrm{~ns}$ performance. Pulses shorter than 1 ns can create larger intensities but will propagate through the pinhole before closure. For longer pulses the chain $B$ values decrease thereby reducing the pinhole loading. The calculation of pinhole sizes of course depend upon the noise model used. In our calculation we used a model that gives good agreement with the noise spectra observed for the Argus and Shiva lasers.

\section{GLASS PROPERTIES}

Choice of phosphate glass for Nova was predicated upon the following consinerations: 1) low nonlinear index-of-refraction; 2) high gain; 3) saturation fluence parameters competitive with silicate $\boldsymbol{c}_{\text {i lasses; }}$ 4) proven performance in laser systems; and 5) reasonable cost. Listed in Table 2 are solne important physicai properties of this class, along with properties of ED-2 silicate glass used extensive!y in previous systems.

Shown here are the lasing waveiength, $\lambda_{i}$ crnss-section for stinulated emission, $\sigma_{p}$; fluorescence lifetime, $T$; linewidth, $\Delta T$; linear index-of-refraction, $n_{0}$; nonlinear index-of-refraction, $n_{2}$; and saturation fluence, $E_{s}$. The saturation fluence $E_{s}$ shown in Table 2 corresponds to a value for which the output fluence from the test sample was $5 \mathrm{~J} / \mathrm{cm}^{2}$.

Recent experiments have shown that the saturation fluence is dependent upon the fluence level. Figure 2 illustrates this for LHG-8 glass. The saturation values shown in Table 2 are a valid 
comparison since all test samples were pumped to approximately the same small signal and net gains. From our data, we conclude that. the saturation properties of phosphate glasses are superior to ED-2-type silicate glasses over the range of fluences of interest for Nova. We acrount for the variation of $E_{s}$ with flience in our system performance calculations.

The specifications on the bulk properties of production phosphate glass are:

$$
\begin{aligned}
& \text { Attenuation }\left(\mathrm{cm}^{-1}\right) \leq 0.0015 \\
& \text { Homagene } f \text { ty }= \pm 1 \times 10^{-6} \\
& \text { Damagge Fiuence }\left(\mathrm{J} / \mathrm{cm}^{2}\right) \geq 35 .
\end{aligned}
$$

The damage fluence quoted above is relative to the beam in air, actual fluence in a tilted disk is reduced by the index of refraction.

\section{AMPLIFIER DESIGN}

A new more efficient box arolifier tesign has been adopted for the 208, 315, and $460 \mathrm{~mm}$ aperture disks. The 315 and $208 \mathrm{~mm}$ designs are scaled in size from the 240 proiotype amplifier that has been experimentally evaluated. Both the 315 and $208 \mathrm{~mm}$ heads use standard Shivo lamps (112 $\mathrm{cm}$ are length) mounted longitudinally with respect. to the ax is of the ampliffer. The $460 \mathrm{mmll}$ head uses short ( $48 \mathrm{cin}$ arc length) lamps similar to those used on the shiva rod amplifiers. They are mounted transverse to the $a x$ is of the amplifier. To suppress parasitic oscillation the disks in the $460 \mathrm{~mm}$ amplifier are split perpendicular to their long axis. In other aspects the design of the 160 man head is similar to the $315 \mathrm{~nm}$ hear.

Table 3 shows some important design characteristics of the 315 and 460 mom amplifiers.

\section{FREQUENCY CONYERSION}

The $0.53 \mathrm{~mm}$ target irraciating beam will be generated at a positiun between the last turning mirror and the taroet focusing optics by passing the $74 \mathrm{~cm}$ beam through an array of KDP frequency doubling crystals. The Fresnel reflection losses from the crystals will be minimized by placing them between two antireflection (AR) coated windows which are index-matched to the KDP crystal material with a fluid. The individual crystals of the array will be precision cut to the appropriate phase matching angle by computer controller diamond turning techniques. This accurate finishing of the crystals in 
concert with their initial precision alignment in the array w1ll obviate the need for individual seginent adjustments. After assembly the array will perform as a single monolithic crystal. The crystal thickness has been chosen to optimize $2 \omega$ energy conversion efficiensy over the anticipated operating range of the system.

Specifications for the doubling array are given in Table 4. FLUENCE LIMITATIONS: $1.05 \mathrm{\mu m}$

Performance of Novette, as with our other glass laser systems, is limited by the threat of beam induced damage to optical components. In present systems, the greatest threat has been to AR cootings on the input lenses of spatial filters and on the target focusing optics. To achieve higher performance with Novette, we will increase the damage resistance of the spatial filter input lenses by using uncoated optics. The reduction in beam intensity resulting from the geometrical beam expansion and the reduction in beam noise modulation by the spatial filter (SF) element greatly reduces the peak fluence at the SF exit lenses. This permits use of AR coatings on the SF exit lenses and target focusing optics with a minimal risk of beam induced damage. Coated polarizers and high reflection surfaces typically have higher damage thresholds at $1.05 \mu \mathrm{m}$ than AR coated surfaces and therefore, do not 1 imit the performance of the current Novette design. Bulk damage thresholds are not anticipated to be a threat.

To assess the threat of surface damage and to develop guidelines for Novette chain design, we adapted the following rules generated by the Nova team from available damage data.

1) Bulk glass damage and damage to high reflection (HR) coatings are presently not limiting performance.

2) For 1 ns pulses, uncoated surfaces damage at a median fluence of $16 \mathrm{~J} / \mathrm{cm}^{2}$, with $70 \%$ of the surfaces tested damaging between $14-19 \mathrm{~g} / \mathrm{cm}^{2}$. At other pulse lengths (0.1 to $\left.3 \mathrm{~ns}\right)$ incoated surface damage appears to follow a $\sqrt{T}$ dependence.

3) Antireflection surfaces damage at 1 nsec ot a median fluence of $5 \mathrm{~J} / \mathrm{cm}^{2}$ with $80 \%$ of the surfaces tested damaging between $4-7 \mathrm{~J} / \mathrm{cm}^{2}$. In addition, their damage threshold appears to increase slightly between 1 and 3 ns and appears to scale as $\sqrt{\tau}$ for pulses shorter than 1 ns. 
4) There is a reasonable expectation that damage thimesholds will increase. This expectation is based upon recent progress with graded-index AR surfaces, super polish AR coatings and laser polishing of uncoated surfaces.

With these guidelines the Nova team established three fluence groups for which to target the Nova $1.05 \mu m$ design. These groups are referred to as the "A", "B", and "C" fluence groups. Table 5 shows the thresholds for coated and uncoated surfaces in each group. The thresholds in the "A" group represent the median values obtainable today. More specifically, the I ns values are the median vaiues obtained by examining a large number of data taken at this puise length. Values at other pulse lengths are then determined using rules 2 and 3 above. Thresholds shown for the "B" group represent the highest values obtainahle from today's production coatings and surfaces. Again, values at other pulse durations are scaled from the $1 \mathrm{~ns}$ data. The " $C$ " values represent an estimate of what may be possible in the future if one or more of several advanced approaches can be brought to production. Presently, graded-index surfaces look the most promising, with both Schott and Hoya mounting a significant development effort. Less developed are the techniques of laser polishing and super-polishing of substrate surfaces. Research samples have shown that a significant increase in damage threshold of a bare surface can be obtained by simply "burnishing" the surface with a directed $\mathrm{CO}_{2}$ laser beam. In the case of super polish in which the substrate is finished with a bowl-feed process, there is evidence that damage thresholds for AR coatings applied to such surfaces are increased. (Both laser and super polish techniques are presently in a very elementa? state and herice should be viewed as "long shot".) Optics in the initial Novette procurements will mostly be finished and coated using present technology and will restrtct initial operating levels to those obtainable with "Aa fluences.

Perhaps our greatest short-term hope is for graded tndex parts suitable for damage free laser operation at the "B" fluence levels.

FLUENCE LIMITATIONS: $0.53 \mu \mathrm{m}$

The $74 \mathrm{~cm}$ aperture optical train required to generate and transport the $0.53 \mu \mathrm{m}$ beam to the target focusing ontics is shown in Figure 1 . Although the threat of damage to these optical elements is not inordinately high, it is st 111 a matter of concern. (Recent 1 rs measurements indicate that the $0.53 \mu m$ 
and 1.05 w demage thresholds are comparable (see Table 6).) in accordance with our previous aiscussion, we have assigned "A" and "B" fluence levels at $0.53 \mathrm{~m}$ according to the "rules" discussed earlier; i.e., "A" fluence is the median vaiues obtainable touay and the "B" group represents the highest values obtafnable from today's production coatings. Table 7 gives the "A" and " $B$ " fluence Tevels at $0.5 .2 \mu \mathrm{m}$.

MOVETTE TARGET IRRADIATION GEOMETRY

The primary mission of Novette is to perform $0.53 \mu \mathrm{m}$ target experiments for direct comparison with those conducted at $1 \mu \mathrm{m}$ on Shiva. Ultimately this will require a $74 \mathrm{~cm}$ focusing systen with an $f$-number of 1.5 or less. Unfortunately, conventional lenses of this speed limit performance due to intensification of flux on the exit surface of the lens, while an advanced all reflecting system cannot be fabricated in tine for the Juiy, 1982 target shot. An intermediate $f / 2$ focusing system using Novs beam diagnostic lenses has been chosen for the baseline. This choice was madc because the f-number is near that desired, the lenses are now in fabrication, and the danage-limited performance is superior to the $f / 1.5$ lenses. A decision regarding use of an all reflecting system will òe made later.

An all reflecting focusing system. such as the axicon shown in Figure 3, is viewed as the best candidate for the advanced system. This type of all reflecting system has the benefit of being free of chromatic aberration and avoids the absorption and nonlinear propagation effects inherent in transmitting optic5. Another advantage of the axicon is the reduction in the damage threat that comes from reduced beam fluence and the higher damage thresholds of reflective coating. Since present specifications require a focal accuracy of 20 microradians, not the 0.4 mferoradian tolerance of a $0.53 \mu m$ diffraction limited system, fabrication will be difficull but is within the present state of the art.

An $f / 1.5$ clamshell "back-up" option is shown in Figure 4 . It is less desirab le but meets the $f / 1.5$ specification using a combination of spherical "clamshell" mirrors and an $\mathrm{f} / 3$ aspheric lens (or corrector plate). In this scheme a different refractive element would probably be required for each wavelength and protection of the mirror from target debris presents 3 serfous operating problem. 
However, this option is under consideration because relative to the axicon it has a greatiy reduced cost and less technical risk. In sunmary, the baseline design uses Nova c/2 beam diagnostic lenses for in it ial activation (see Table 8 for further specifications). If practical. an all reflecting system will he installed later; if not, the "back-up" $f / 1.5$ "clamshell" could be used to provide the required fast tarnet focusing.

\section{NOVETTE LASER PERFORMANCE}

The physical characteristics (i.e., diameter, thickness, iinear and lion 1 inear refractive indices, and the small sional qain) of the Novette optical elements are listed in Table 9.

With these component parameters, we used the MALAPROP conputer code to simu'ate the performance of the baseline chain. Figures 5-7 summarize the resilts of thesc calculations in graphic and tabular form. The summary includes the beam enerqy, the peak energy density, the mean energy density, and the ratio of the peak to mian energy densitier of the bear at tne entrance and exit lenses of the spatial filters and the interstage $D$. :lues between spatial filter pinholes. For "A" fluences, damage to AR coated optics at pither the exit ienses cf the large aperture spatial filters or the focusing optics Jimits the chain pe. Folmance. Since both the peak and mean fluences steadily increase with increasing beam diameter, all other optica i elemf., cs of the chain are well helow their damage threshold. At these conservative "A" damage fluences, each bei" can provide eight terawatts during short pulse ( $T \leq 1$ ns) oderation and 10.5 kilojoules during̣ lunner pulse (3-5 ns) operation.

At "B" fluences fam bear can provide 0.4 terawatts furing rhort pulse operation. In tinis case the damage threat shirts from the coated outics to the lacoates entrance lenses of the final two spatial filters. At this high power level the systein is primarily lumited by the large peak to average beam modulation introduced by nonlinear self-focusing. At " $B$ " fluences with long pulses ( $T \geq 3$ ns) the chain is 1 imited by gain saturation and energy storage as much as by damage threats. The amplification stages prior to the 460 in stage must be drivon into deep saturation to obtain the required drive for 
the $460 \mathrm{~mm}$ heads. In this regime the exit lenses of the find two spatial filters and the target focusing optics all experience about the same damage threat. At " $B$ " fluences in the long pulse regime each chain can de 7iver $13.5 \mathrm{~kJ}$ to the target.

The large number of components subject to damage risk at " $B$ " fluences for long pulse durations prompted us to investigate a more conservative chain staging. Figures 8-10 compare the code

calculations for a chain with an additional $160 \mathrm{~mm}$ amplifier to the baseline. Altholigh the performance with the additiond amplifier is slightiy degraded at 1 ns, down to 8.75 teravatts per beam from 9.4 terawatts, long pulse performance improves and the damage threat is supstantially reduced.

We projected the frequency doubled performance $(0.53 \mu \mathrm{m})$ from the $1,05 \mu \mathrm{m}$ performance with the aid of two additiona 7 computer codes: ENERG-2w and X-GAP. The code ENERG-2w calculates energy conversion efficiency and was usfd to optimize the KDP doubling crystal thickness for the operat ing range of the system. These optimization calculations assumed that the overall beam divergence and crystal alignment errors did not exceed 100 microradians. Figure 11 shows the conversion efficiency of the aptimum (18 miu) thickness crystal. Arter establishing the conversion efficlency, we estimated the energy on target by reducing the $0.53 \mu \mathrm{m}$ heam energy exiting the crystal by the following transmission losses:

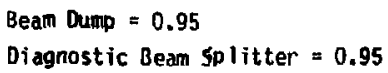

X-GAP and MALAPROP coje calci:lations predicted any additional beam modulation caused by diffraction from the crystal interstices and its subsequent growth through the optfcal train from the crystal to the target focusing optics,

Figure 12 is a sumary of the performance calculations and shows the aperating envelope (1.e., energy deliverable to a target vs. pulse lenith) for the baseline chain. Curves are shown for b:ith "A" and " $B$ " fluences for $1.05 \mathrm{~mm}$ and $0.53 \mathrm{~mm}$ beams. The cross hatched regions denote the 100 microradian 
uncertainty in the frequency doubled phase matching condition. Each frequency doubled beam can provide between 5 and 7.5 terawatts for short puises and 6 to $10 k i$ lojoules of energy for a pulse duration of 1 to 3 nanoseconds. For 3 to 5 nanosecond pulses, the $1.05 \mu \mathrm{m}$ bean intensfty at the crystal is less than opt imum reducing the $0.53 / \mathrm{mm}$ beam energy to $6-8$ kilojoules. Finally, Figure 13 summarizes the system performance with an additfonal $460 \mathrm{~mm}$ amplifier. This staging produces higher $1.05 \mu \mathrm{m}$ beam intensities at the crystal for pulse durations between 3 and $5 \mathrm{~ns}$. The improved frequency doubling conversion efficiency in this case would produce about one addit onal kilojoule per arm of $0.53 \mu \mathrm{m}$ light in the 3-5 nanosecond regime.

In sunmary, a baseline design for the two-arm Novette system has been deveioped to provide target irradiation at fundamental and second harmonic wavelengths. The initial system performance is predicated on operating at "A" fluence levels with capability of providing output conanensurate with "B" fluences if appropriate large aperture optics can be obtained. At the " $A$ " fluences and the fundamental wavelangth, it can dolivar on targot 10 to 16 torawatle of peak powew for short $(\leqslant 1 \mathrm{~ns})$ pulses, and 15 to $20 \mathrm{kilojoules}$ of energy for longer 3-5 $\mathrm{ns}$ pulses. Second harmonic pdwer and energy on target are typically 80-85\% of these levels. The maximum fluences associated with these performance projections are within " $A$ " fluence damage levels at the respective wavelergths, indicating that routine target irradiation at these powers in denergies are possible with minimal damage risk to critical large aperture optics

ACKNOWLEDGENENTS

We are indebted to W. W. Simmons, J. A. Glaze, J. B. Trenholme, and W. F. Hagen, authors of UCID 18793, from which certain sections of this report were derived. We also express our thanks to the scientists and engineers of Fusion Lasers (Y-Program) for their valuaiole contributions. Finally, we thanik Diane Kelly for preparing the manuscript. 


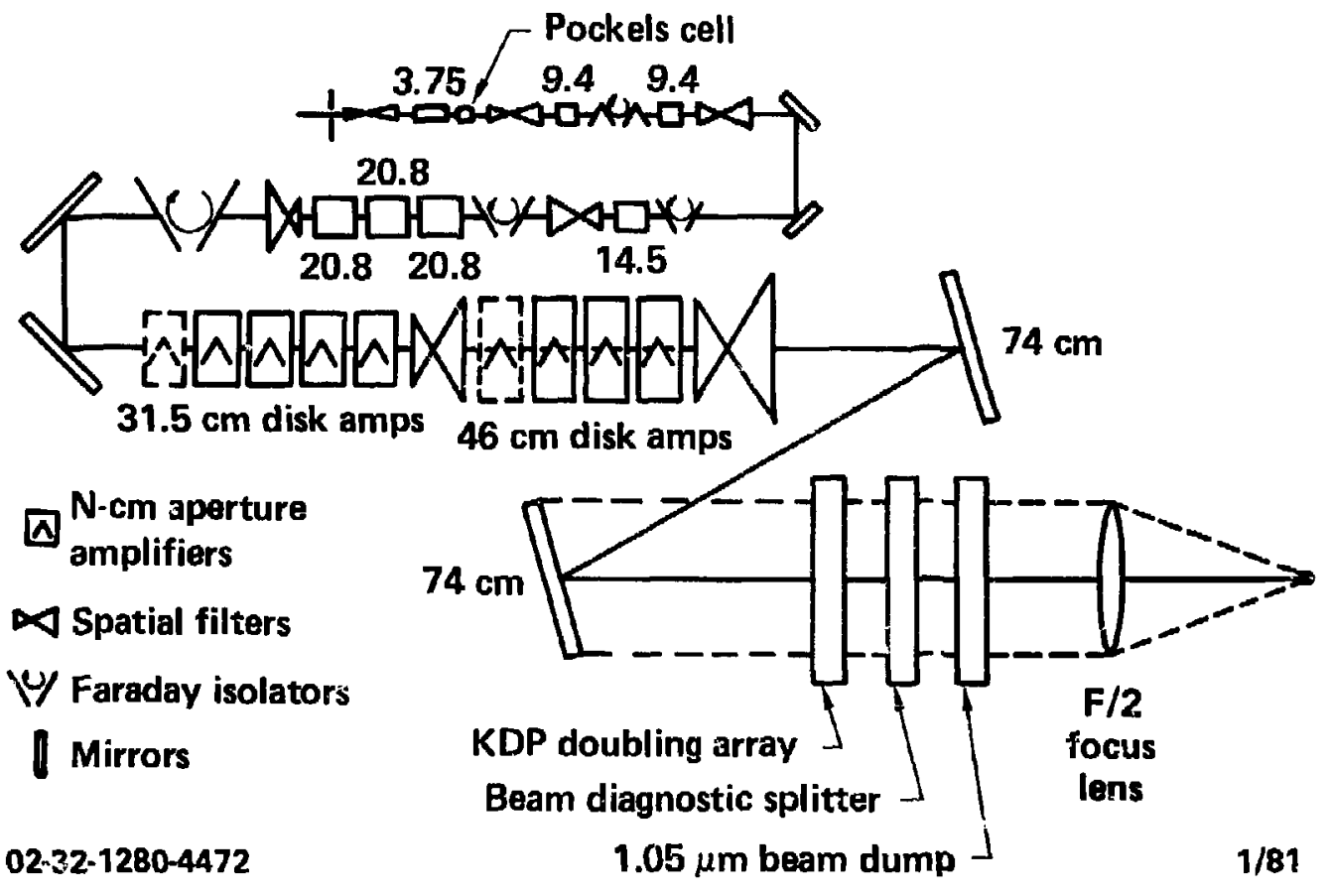

Fig. 1 
Table 1: Novette Chair Spatial Filter/Relay Parameters

\begin{tabular}{|c|c|c|c|}
\hline Filter Relay & f-Number & Pinhole Qiameter (m) & $\begin{array}{l}\text { Angu lar Acceptance } \\
\text { Aperture ( } \mu \mathrm{rad})\end{array}$ \\
\hline $460 \mathrm{~mm} / 740 \mathrm{~mm}$ & 20 & 2.3 & 250 \\
\hline $315 \mathrm{~mm} / 460 \mathrm{~mm}$ & 16.5 & 1.25 & 240 \\
\hline $208 \mathrm{~mm} / 315 \mathrm{~mm}$ & 20 & 1.0 & 240 \\
\hline $150 \mathrm{~mm} / 208 \mathrm{~mm}$ & 20.8 & 0.8 & 357 \\
\hline $91.7 \mathrm{~mm} / 150 \mathrm{~mm}$ & 10.6 & 0.3 & 308 \\
\hline $37.5 \mathrm{~mm} / 91.7 \mathrm{~mm}$ & 22.9 & 0.64 & 745 \\
\hline $27 \mathrm{~mm} / 37.5 \mathrm{~mm}$ & 72 & 1.9 & 873 \\
\hline
\end{tabular}


Table 2: Properties of Phosphate Amplifier Glasses

\begin{tabular}{|c|c|c|c|c|c|c|c|c|}
\hline Phosphate & Vendor & $\underline{\lambda(\mu \mathrm{m})}$ & $\sigma_{\left(\mathrm{pm}^{2}\right)}$ & $\underline{\tau(\mu \mathrm{s})}$ & $\Delta \lambda(\mathrm{nm})$ & $\underline{n_{0}}$ & $n_{2}\left(10^{-13}\right.$ esu $)$ & $E_{s}(1 \mathrm{~ns})$ \\
\hline LHG-8 & Hoya & 2.053 & 4.0 & 400 & 25.9 & 1.520 & 1.1 & 4.5 \\
\hline Q-88 & Kigre & 1.054 & 0.0 & 400 & 26.3 & 1.53 & 1.1 & 3.6 \\
\hline LHG-750 & Schatt & 1.053 & 4.0 & 400 & 25.5 & 1.515 & 1.1 & - \\
\hline$\overline{\mathrm{ED}-2}$ & $0 . \mathrm{I}$. & 1.064 & 2.7 & 350 & 34.4 & 1.56 & 1.41 & $\overline{4.5}$ \\
\hline
\end{tabular}

Silicate 


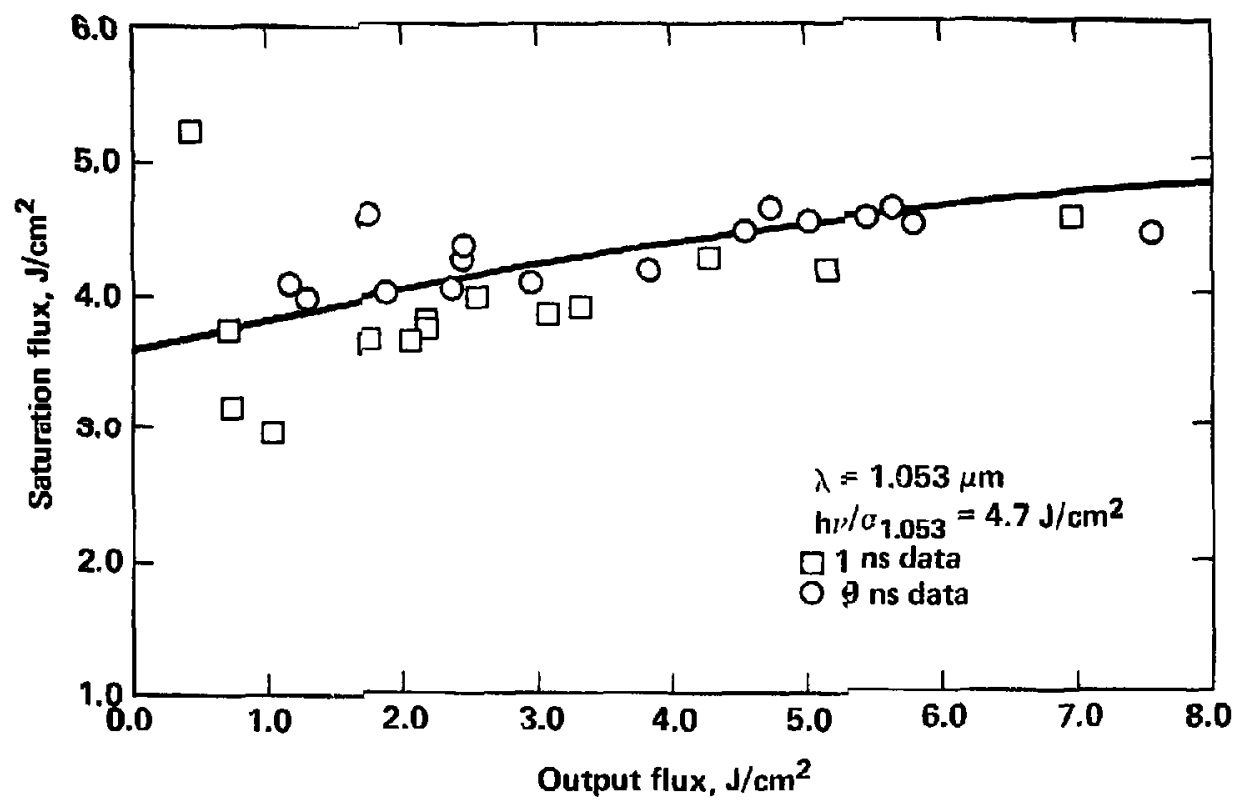

$50.50-0979 \cdot 3054$ 
Table 3: Phosphate Amplifjer Designs

\begin{tabular}{lcc}
\multicolumn{1}{c}{ Clear Aperture } & $\frac{315 \mathrm{~mm}}{43 \mathrm{~mm}}$ & $\frac{460 \mathrm{~mm}}{43 \mathrm{~mm}}$ \\
Thickness & 2 & 2 (split) \\
Disks Per Module & 1.78 & 1.93 \\
SS Gain Per Hodule & 5.6 & 6.2 \\
Gain Coefficient & $260 \mathrm{~J} / \mathrm{L}$ & $290 \mathrm{~J} / \mathrm{L}$ \\
Energy Density & $14 \mathrm{~L}$ & $28 \mathrm{~L}$ \\
Glass Volume Per Module & $375 \mathrm{~kJ}$ & $600 \mathrm{~kJ}$ \\
Bank Energy Per Module & 3.5 & 3.2 \\
OD & &
\end{tabular}




\section{Table 4: Crystal Ooubling Assfmbly Specifications}

\section{Crystals}

- Material.

- Type of Cut:

- Geometrical Shape:

- Array I

Total Number of Crystals:

Length:

Width:

Thickness

- Spacing Between Adjacent Crystals:

Finishing Tolerance:

- Array 11

Total Number of Crystals:

Length:

Width:

Thickness:

Spacing Between Adjacent Crystals:

Finishing Tolerance:

\section{KDP (Potassium DUHydrogen Phosphate)}

Type II $\left(\theta_{\mathrm{m}}=59.23^{\circ}\right)$

Square Paralle lepiped

$25+5$ Spares

$150 \mathrm{~mm} \pm .01$

$150 \mathrm{~mm} \pm .01$

$18 \mathrm{~mm} \pm .01$

25 to $200 \mu \mathrm{m}$

\pm 60 urad from Optimum Phase Matching Angle

\pm 1 mrad in Other Principal Ax is Directions

$9+3$ Spares

$260 \mathrm{~mm} \pm . .1$

$260 \mathrm{~mm} \pm .01$

$18 \mathrm{~mm} \pm .01$

25 to $100 \mu \mathrm{m}$

\pm 60 urad from Optimua Pilasp Matching

\pm 0.5 mrad in Other Principal Ax is Directions 
Table 4: Crystal Doubling Assemb ly Specifications - (Cont'd)

\section{Windows}

Material:

Clear Aperture Diameter:

Thickness :

AR Coating:

\section{Index-Matching-Fluid}

Materia!:

Layer Thickness:
BK-7

$800 \mathrm{~mm}$

$70 \mathrm{~mm}-100 \mathrm{~mm}$

Exterior Window Surfaces will be finished with conventional AR coating (both

$1.05 \mu \mathrm{m}$ and $0.53 \mu \mathrm{m}$ )

Poly-Chloro-Tr 1 luoroethy lere

(Halocardon 011 "56)

4-10 $\mu \mathrm{m}$ 


\begin{tabular}{|c|c|c|c|c|c|c|}
\hline & \multicolumn{3}{|c|}{ Antireflestion } & \multicolumn{3}{|c|}{ Uncoated } \\
\hline & $100 \mathrm{ps}$ & $1 \mathrm{~ns}$ & $3 \mathrm{~ns}$ & $100 \mathrm{ps}$ & $1 \mathrm{~ns}$ & $3 \mathrm{~ns}$ \\
\hline "A" & $1.6^{*}$ & $5^{*}$ & $5.5^{*}$ & !. $1^{*}$ & $16^{*}$ & $28 *$ \\
\hline "B" & $2.5^{* *}$ & & $8.5^{* t}$ & $6^{* *}$ & $19^{* *}$ & $33^{* *}$ \\
\hline & 777 & & 7 & & & 7777 \\
\hline “C" & $3.8^{++}$ & $12^{+}$ & $12.5^{+}$ & $11^{++t}$ & $35^{4}$ & $61^{t+t}$ \\
\hline
\end{tabular}

- Median damege threshold for today's surfaces

* Damage threshold for best of today's surfaces

++ Super polish

+++ Laser polish/graded index 


\section{LASER DAMAGE THRESHOLDS OF PRODUCTION OPTICAL COMPONENTS (1 ns)}

\begin{tabular}{|l|c|c|}
\hline \multirow{2}{*}{ Surface type } & \multicolumn{2}{|c|}{ Damage threshold, $\mathrm{J} / \mathrm{cm}^{2}$} \\
\cline { 2 - 3 } & $1.05 \mu \mathrm{m}$ & $0.53 \mu \mathrm{m}$ \\
\hline Thin film, AR & $4-7$ & $3-6$ \\
\hline Thin film, HR & $6-10$ & $2-6$ \\
\hline $\begin{array}{l}\text { Beam dump } \\
\text { (separate wave lengths) }\end{array}$ & -- & $2-8$ \\
\hline Bare polished glass & $14-18$ & 18 \\
\hline Gradient index & $10-14$ & $11-13$ \\
\hline
\end{tabular}


Table 7: Novette $0.53 \mu \mathrm{m}$ Design F 7uence Levels

"A" $\mathrm{y} / \mathrm{cm}{ }^{2}$

"B" $J / c \pi^{2}$

\begin{tabular}{|c|c|c|c|c|c|}
\hline \multicolumn{2}{|c|}{ Antireflection } & \multicolumn{2}{|c|}{ High Reflection } & \multicolumn{2}{|c|}{ Uncoated } \\
\hline $1 \mathrm{~ns}$ & $3 \mathrm{~ns}$ & $1 \mathrm{~ns}$ & $3 \mathrm{~ns}$ & $1 r$ & $3 \mathrm{~ns}$ \\
\hline 4.5 & 4.5 & 4.5 & 4.5 & 16 & 28 \\
\hline 6 & 6 & 6 & 6 & 19 & 33 \\
\hline
\end{tabular}




\section{Notes:}

1. Cross section of inner cone is a $90^{\circ}-45^{\circ}-45^{\circ}$ triangle

2. Cross section of outer cone is a parabola given by $z= \pm \gamma^{2} / 2 R$ where

$R=2864.2$

3. All dimensions in millimeters

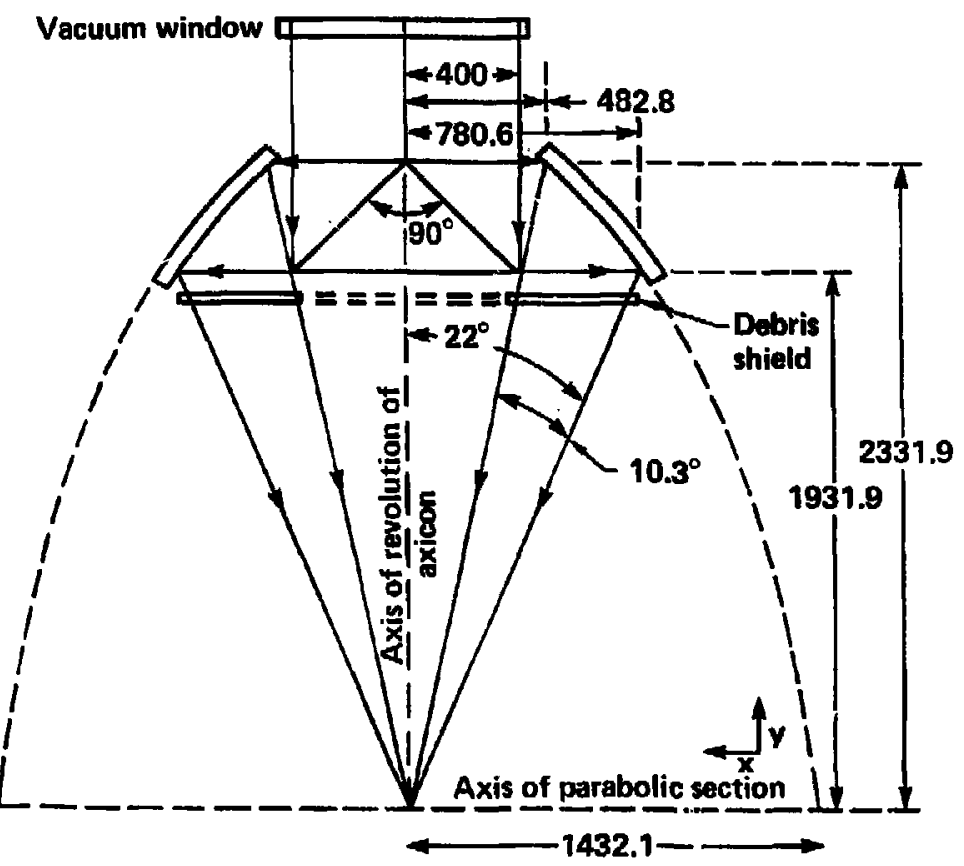

02-32-1180-4138

Fig. 3 


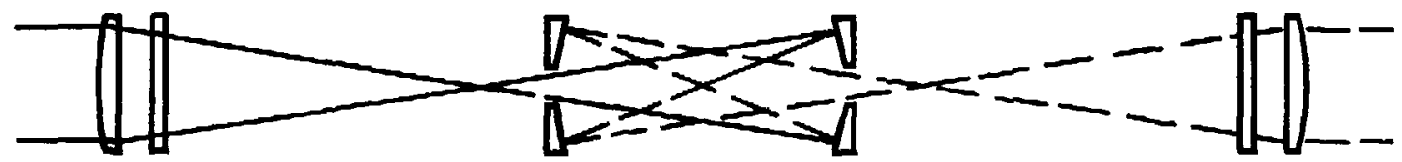

- Axial glass thickness $=130 \mathrm{~mm}$

- Intensification less than $\mathbf{5 \%}$ on vacuum window

- Clamshells are moderately sensitive to tilt (0.2 mrad FOV) 
Table 8: Novette f/2 Target Forusing Lerises

Nova Drawirg Number: AAA 78-116426, Tab Number 06B

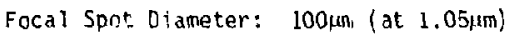

$50 \mu \mathrm{in}(\mathrm{a}: 0.53 \mu \mathrm{m})$

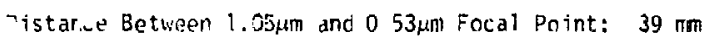

Back to Front Surface Beam intensification: 11\%

Cenzer Thickness: $128 \mathrm{im}$ 
Wavolength $1.053 \mu \mathrm{m}$

Fill tector 0.7

\begin{tabular}{|c|c|c|c|c|c|c|c|}
\hline $\begin{array}{l}\text { Comp } \\
\text { numb }\end{array}$ & $\begin{array}{l}\text { Component } \\
\text { description }\end{array}$ & $\begin{array}{l}\text { Diam } \\
(\mathrm{cm})\end{array}$ & $\begin{array}{l}\text { Thick } \\
\text { (cm) }\end{array}$ & $\begin{array}{l}\text { No, and } \\
\text { ans }\end{array}$ & $\begin{array}{c}\text { Refr } \\
\text { index }\end{array}$ & $\begin{array}{l}\text { Nanin } \\
\text { index }\end{array}$ & $\begin{array}{c}\text { 8s } \\
\text { gin }\end{array}$ \\
\hline 1 & Apodizer & $\overline{2.7}$ & 0 & 1 & 1 & 0 & 1 \\
\hline 2 & SF input & 2.7 & .5 & 1 & 1.507 & 1.24 & 0.90 \\
\hline 3 & Pinhole & & & & & & \\
\hline 4 & 8F output & 3.75 & 0.5 & 1 & 1,507 & 1.24 & 0.99 \\
\hline 5 & Wave plate & 3.76 & 0 & 1 & & 0 & 0.7 \\
\hline 6 & Rod $50 \mathrm{~mm}$ & 3.75 & 40 & 1 & 1.523 & 1.05 & 20 \\
\hline 7 & Pookels' hol & 3.75 & 8.5 & 1 & 1.5 & 1 & 0.87 \\
\hline $\begin{array}{l}8 \\
\text { g }\end{array}$ & $\begin{array}{l}\text { SF input } \\
\text { Pinhole }\end{array}$ & 3.75 & 0.5 & 1 & 1.507 & 1.24 & 0.99 \\
\hline 10 & SF output & 9.17 & 0.8 & 1 & 1.507 & $i 24$ & 0.99 \\
\hline 11 & Disk $94 \mathrm{~mm}$ & 9.17 & 2.4 & 6 & 1.523 & 1.06 & 6.5 \\
\hline 12 & Foraday isol & 9.17 & 4.5 & 1 & 1.67 & 2.1 & 0.88 \\
\hline 13 & Disk $94 \mathrm{~mm}$ & 9.17 & 2.4 & $B$ & 1.523 & 1.05 & 6.5 \\
\hline $\begin{array}{l}14 \\
15\end{array}$ & $\begin{array}{l}\text { SF input } \\
\text { Pinhole }\end{array}$ & 9.17 & 0.8 & 1 & 1.507 & 1.24 & 0.9199 \\
\hline 16 & SF output & 15 & 1.2 & I & 1.507 & 1.24 & 0.89 \\
\hline 17 & Faraday isol & 15 & 2.5 & 1 & 1.67 & 2.1 & 0.92 \\
\hline 18 & Disk $150 \mathrm{~mm}$ & 15 & 3 & 4 & 1.523 & 1.05 & 3.6 \\
\hline $\begin{array}{l}19 \\
20\end{array}$ & $\begin{array}{l}\text { Sf input } \\
\text { Pinhole }\end{array}$ & 15 & 1.2 & 1 & 1.507 & 1.24 & $\begin{array}{l}0.915 J \\
1\end{array}$ \\
\hline
\end{tabular}




\begin{tabular}{|c|c|c|c|c|c|c|c|}
\hline $\begin{array}{l}\text { Comp } \\
\text { numb }\end{array}$ & $\begin{array}{l}\text { Component } \\
\text { description }\end{array}$ & $\begin{array}{l}\text { Diam } \\
(\mathrm{cm})\end{array}$ & $\begin{array}{l}\text { Thick } \\
\text { (cm) }\end{array}$ & $\begin{array}{c}\text { No. and } \\
\text { ang }\end{array}$ & $\begin{array}{l}\text { Refr } \\
\text { index }\end{array}$ & $\begin{array}{l}\text { Nonln } \\
\text { index }\end{array}$ & $\begin{array}{l}\text { sS } \\
\text { gain }\end{array}$ \\
\hline 21 & SF output & 20.8 & 1.7 & 1 & 1.507 & 1.24 & 0.93 \\
\hline 22 & Faraday isol & 20.8 & 4 & 1 & 1.67 & 2.1 & 0.89 \\
\hline 23 & Disk 208 mm [ ] & 20.8 & 2.5 & 3 & 1.523 & 1.05 & 2.2 \\
\hline 24 & Disk $208 \mathrm{~mm}$ & 20.8 & 2.5 & 3 & 1.523 & 1.05 & 2.2 \\
\hline 25 & Disk 208 mm [] & 20.8 & 2.5 & 3 & 1.523 & 1.05 & 2.2 \\
\hline 26 & SF input & 20.8 & 1.7 & 1 & 1.507 & 1.24 & 0.9199 \\
\hline 27 & Pinhole & & & & & & 1 \\
\hline 28 & SF output & 31.5 & 2.5 & 1 & 1.507 & 1.24 & 0.99 \\
\hline 29 & Faraday isol & 31.5 & 2.5 & 1 & 1.67 & 2.1 & 0.9 \\
\hline 30 & Disk $315 \mathrm{~mm}$ [ ] & 31.5 & 4.3 & 2 & 1.523 & 1.05 & 1.7 \\
\hline 31 & Disk $315 \mathrm{~mm}$ [ ] & 31.5 & 4.3 & 2 & 1.523 & 1.05 & 1.7 \\
\hline 32 & Disk $315 \mathrm{~mm}$ [] & 31.5 & 4.3 & 2 & 1.523 & 1.05 & 1.7 \\
\hline 33 & Disk $315 \mathrm{~mm}[]$ & 31.5 & 4.3 & 2 & 1.523 & 1.05 & 1.7 \\
\hline 34 & SF input & 31.5 & 2.5 & 1 &. .507 & 1.24 & 0.9199 \\
\hline 35 & Pinhole & & & & & & 1 \\
\hline
\end{tabular}




\begin{tabular}{|c|c|c|c|c|c|c|c|}
\hline $\begin{array}{l}\text { Comp } \\
\text { numb } \\
\end{array}$ & $\begin{array}{l}\text { Component } \\
\text { description }\end{array}$ & $\begin{array}{l}\text { Diam } \\
(\mathrm{em})\end{array}$ & $\begin{array}{l}\text { Thick } \\
\text { (cin) } \\
\end{array}$ & $\begin{array}{l}\text { No. and } \\
\text { ang }\end{array}$ & $\begin{array}{c}\text { Refr } \\
\text { index }\end{array}$ & $\begin{array}{l}\text { Nonin } \\
\text { index } \\
\end{array}$ & $\begin{array}{l}\text { SS } \\
\text { gain }\end{array}$ \\
\hline 36 & SF output & 46 & 3.7 & 1 & 1.507 & 1.24 & 0.99 \\
\hline 37 & Slit apodizer & 46 & 3 & 1 & 1.507 & 1.24 & 0.99 \\
\hline 38 & Disk $460 \mathrm{~mm}$ [1] & 46 & 4.3 & 2 & 1.523 & 1.05 & 1.85 \\
\hline 39 & Disk $460 \mathrm{~mm}[1]$ & 46 & 4.3 & 2 & 1.523 & 1.05 & 1.85 \\
\hline 40 & Disk 460mm [1] & 46 & 4.3 & 2 & 1.523 & 1.05 & 1.85 \\
\hline 41 & SF input & 46 & 3.7 & 1 & 1.507 & 1.24 & 0.9199 \\
\hline 42 & Pinhole & & & & & & 1 \\
\hline $\begin{array}{l}43 \\
44\end{array}$ & $\begin{array}{l}\text { SF output } \\
\text { Turning mirror }\end{array}$ & $\begin{array}{l}74 \\
74\end{array}$ & $\begin{array}{r}5.9 \\
10.3\end{array}$ & $\begin{array}{l}1 \\
1\end{array}$ & $\begin{array}{l}1.507 \\
1.507\end{array}$ & $\begin{array}{l}1.24 \\
1.24\end{array}$ & 0.99 \\
\hline 45 & Turning mirror & 74 & 10.3 & 1 & 1.507 & 1.24 & 0.97 \\
\hline 46 & Crystal window & 74 & 10 & $i$ & 1.507 & 1.24 & 1 \\
\hline 47 & KDP crystal & 74 & 1.8 & 1 & 1.482 & 1.0 & $0.65-0.90$ \\
\hline 48 & Crystal window & 74 & 10 & 1 & 1.507 & 1.24 & 1 \\
\hline 49 & Diag splitter & 74 & 8 & 1 & 1.507 & 1.24 & 0.95 \\
\hline 50 & $1.05 \mu$ beam dump & 74 & 3 & 1 & 1.507 & 1.24 & 0.95 \\
\hline $\mathbf{5 1}$ & $\begin{array}{l}\text { Target chamber } \\
\text { window }\end{array}$ & 74 & 6.5 & 1 & 1.507 & 1.24 ) & \\
\hline \multirow[t]{4}{*}{52} & Focusing optics & & & & & & 0.93 \\
\hline & $f / 2$ lens & 74 & 128 & 1 & 1.507 & 1.24 & \\
\hline & Debris shield & 74 & 1.5 & 1 & 1.507 & 1.24 & \\
\hline & or axisan. & $74-150$ & - & 1 & - & - & \\
\hline
\end{tabular}




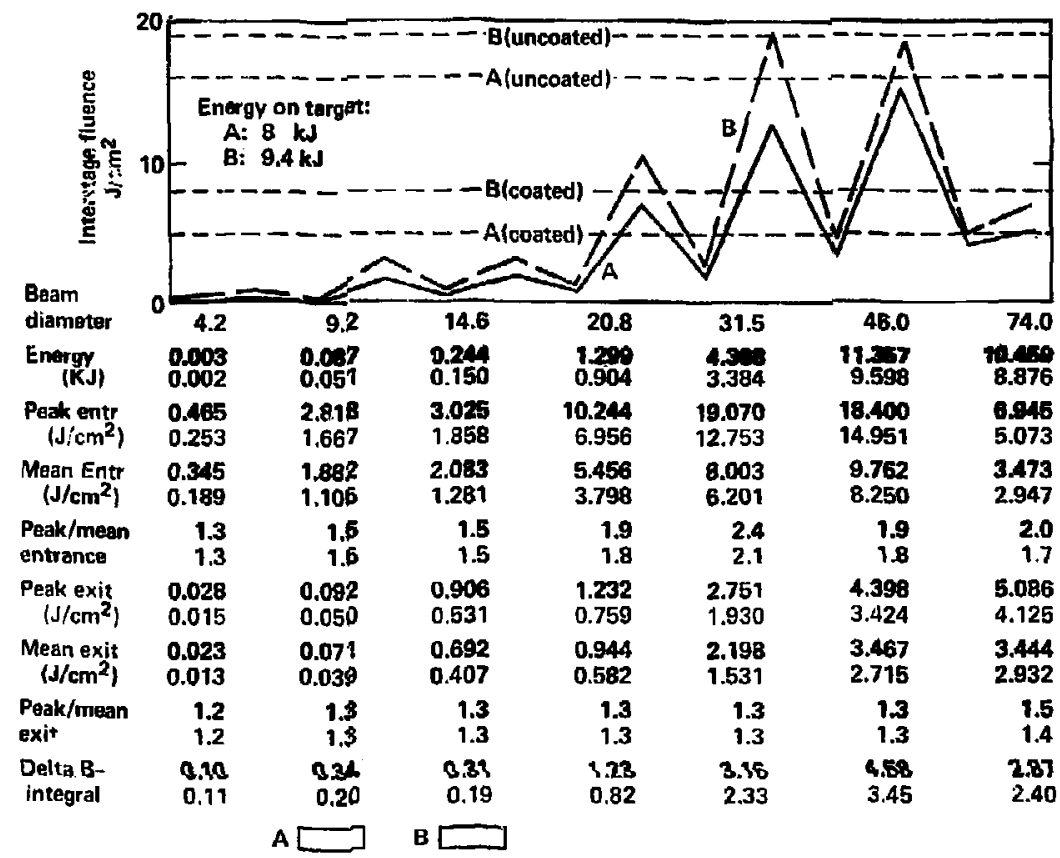

02-32-1280-4506 


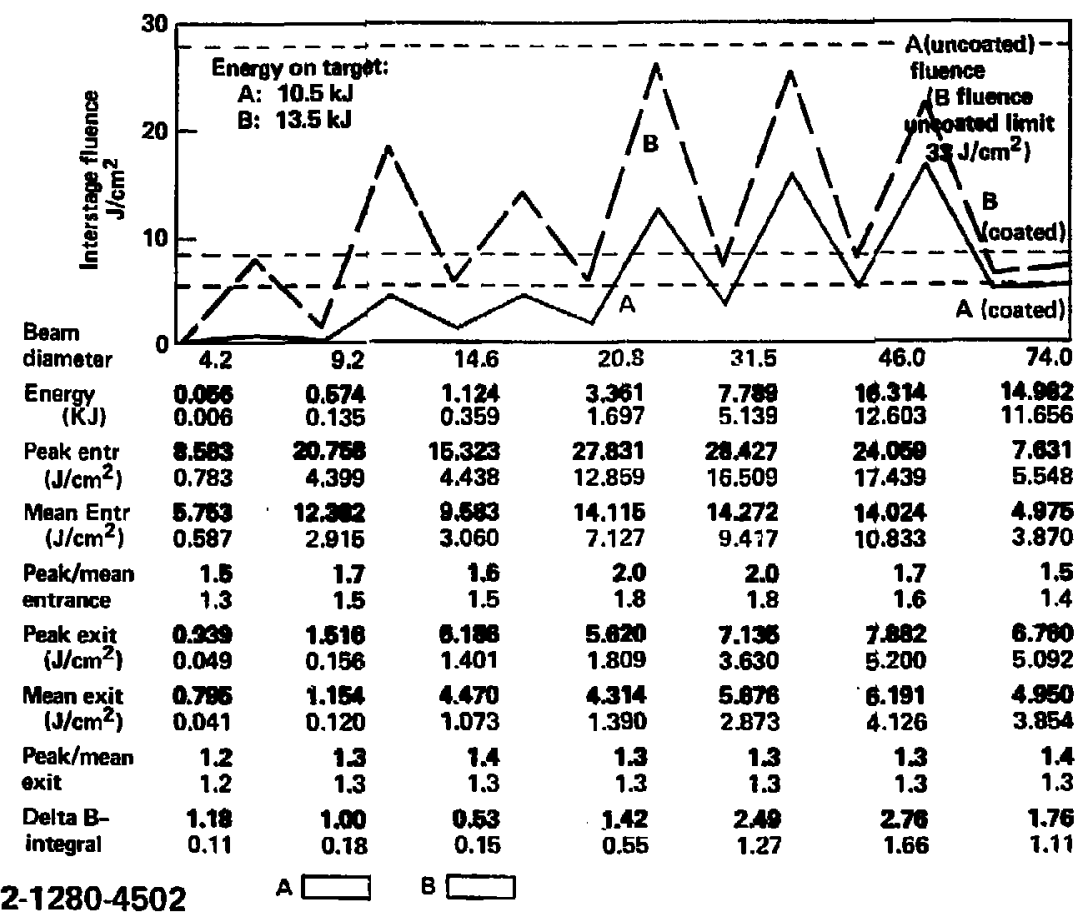




\section{PROJECTED NOVETTE BASELINE CHAIN PERFORMANCE AT $5 \mathrm{~ns}$}

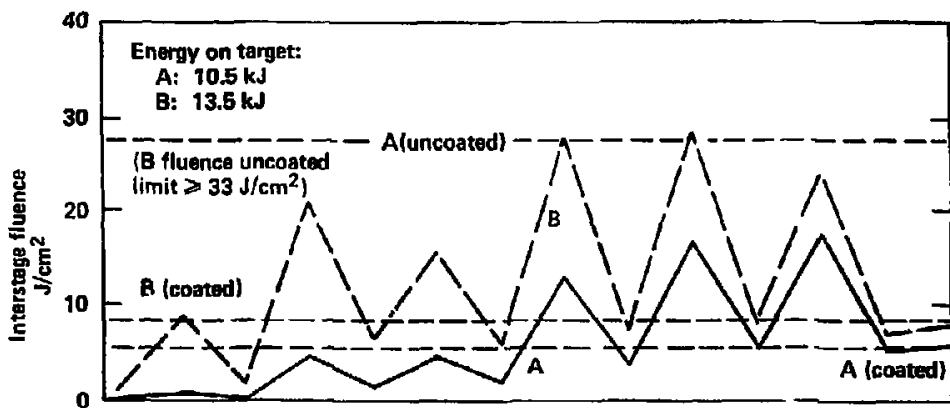

\begin{tabular}{|c|c|c|c|c|c|c|c|}
\hline $\begin{array}{l}\text { Beam } \\
\text { diameter }\end{array}$ & 4.2 & 9.2 & 14.6 & 20.8 & 31.5 & 46.0 & 74.0 \\
\hline $\begin{array}{c}\text { Energy } \\
\text { (KJ) }\end{array}$ & $\begin{array}{l}0.056 \\
0.006\end{array}$ & $\begin{array}{l}0.570 \\
0.135\end{array}$ & $\begin{array}{l}1.122 \\
0.359\end{array}$ & $\begin{array}{l}3.352 \\
1.696\end{array}$ & $\begin{array}{l}7.787 \\
5.139\end{array}$ & $\begin{array}{l}16.202 \\
12.603\end{array}$ & $\begin{array}{l}14.905 \\
11.655\end{array}$ \\
\hline $\begin{array}{l}\text { Peak entr } \\
\left(\mathrm{J} / \mathrm{cm}^{2}\right)\end{array}$ & $\begin{array}{l}8.027 \\
0.779\end{array}$ & $\begin{array}{r}18.227 \\
4.406\end{array}$ & $\begin{array}{r}14.030 \\
4.428\end{array}$ & $\begin{array}{l}25.933 \\
12.578\end{array}$ & $\begin{array}{l}25.020 \\
15.842\end{array}$ & $\begin{array}{l}22.391 \\
16.689\end{array}$ & $\begin{array}{l}7.253 \\
\mathbf{5 . 4 1 0}\end{array}$ \\
\hline$\underset{\left(J / \mathrm{cm}^{2}\right)}{\operatorname{Mean} \text { Entr }}$ & $\begin{array}{l}5.651 \\
0.586\end{array}$ & $\begin{array}{r}12289 \\
2.914\end{array}$ & $\begin{array}{l}9.557 \\
3.059\end{array}$ & $\begin{array}{r}14.077 \\
7.125\end{array}$ & $\begin{array}{r}14.260 \\
9.416\end{array}$ & $\begin{array}{l}13927 \\
10.833\end{array}$ & $\begin{array}{l}4.978 \\
3.870\end{array}$ \\
\hline $\begin{array}{l}\text { Peak/mean } \\
\text { entrance }\end{array}$ & $\begin{array}{l}1.4 \\
1.3\end{array}$ & $\begin{array}{l}1.5 \\
1.5\end{array}$ & $\begin{array}{l}1.5 \\
1.4\end{array}$ & $\begin{array}{l}1.8 \\
1.8\end{array}$ & $\begin{array}{l}1.8 \\
1.7\end{array}$ & $\begin{array}{l}1.6 \\
1.5\end{array}$ & $\begin{array}{l}1.5 \\
1.4\end{array}$ \\
\hline $\begin{array}{l}\text { Peak exit } \\
\qquad\left(\mathrm{J} / \mathrm{cm}^{2}\right)\end{array}$ & $\begin{array}{l}0.939 \\
0.049\end{array}$ & $\begin{array}{l}1.501 \\
0.156\end{array}$ & $\begin{array}{l}5.927 \\
1.386\end{array}$ & $\begin{array}{l}5.655 \\
1.797\end{array}$ & $\begin{array}{l}7.224 \\
3.624\end{array}$ & $\begin{array}{l}7.915 \\
5.200\end{array}$ & $\begin{array}{l}6.873 \\
5.756\end{array}$ \\
\hline $\begin{array}{l}\text { Mean exit } \\
\left(\mathrm{J} / \mathrm{cm}^{2}\right)\end{array}$ & $\begin{array}{l}0.786 \\
0.041\end{array}$ & $\begin{array}{l}1.146 \\
0.120\end{array}$ & $\begin{array}{l}4.476 \\
1.072\end{array}$ & $\begin{array}{l}4.311 \\
1.390\end{array}$ & $\begin{array}{l}\text { 5.676 } \\
2.873\end{array}$ & $\begin{array}{l}6.193 \\
4.126\end{array}$ & $\begin{array}{l}4.854 \\
3.855\end{array}$ \\
\hline $\begin{array}{l}\text { Poak/mean } \\
\text { exit }\end{array}$ & $\begin{array}{l}1.2 \\
1.2\end{array}$ & $\begin{array}{l}1.3 \\
1.3\end{array}$ & $\begin{array}{l}13 \\
13\end{array}$ & $\begin{array}{l}1.3 \\
1.3\end{array}$ & $\begin{array}{l}1.3 \\
1.3\end{array}$ & $\begin{array}{l}1.3 \\
1.3\end{array}$ & $\begin{array}{l}1.3 \\
1.3\end{array}$ \\
\hline $\begin{array}{l}\text { Delta B- } \\
\text { integral }\end{array}$ & $\begin{array}{l}1.25 \\
0.12\end{array}$ & $\begin{array}{l}1.01 \\
0.19\end{array}$ & $\begin{array}{l}0.55 \\
0.15\end{array}$ & $\begin{array}{l}1.45 \\
0.56\end{array}$ & $\begin{array}{l}2.81 \\
1.44\end{array}$ & $\begin{array}{l}0.40 \\
0.22\end{array}$ & $\begin{array}{l}0.69 \\
0.38\end{array}$ \\
\hline $280-4$ & & 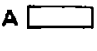 & & Fig. & & & \\
\hline
\end{tabular}


PROJECTED NOVETTE CHAIN PERFORMANCE

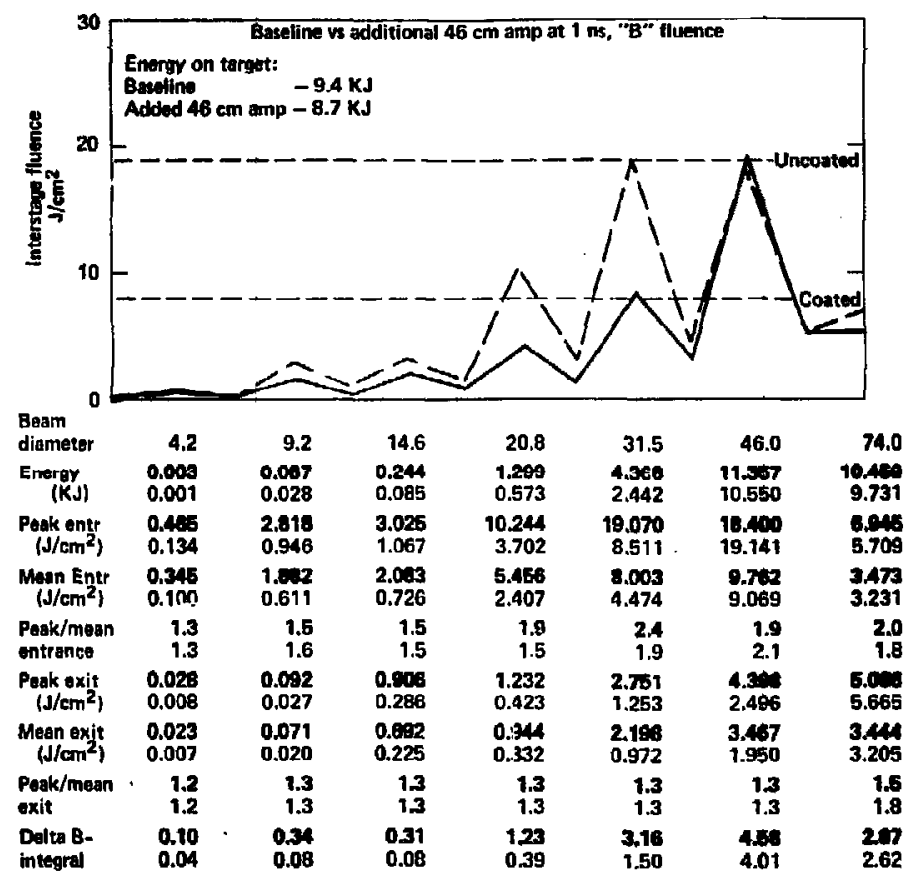

\section{$02-32-1280-4503$}

Baseline - dashed curve \& shaded data
Additional Amp - solid curve \& unshaded data

Fig. 8 


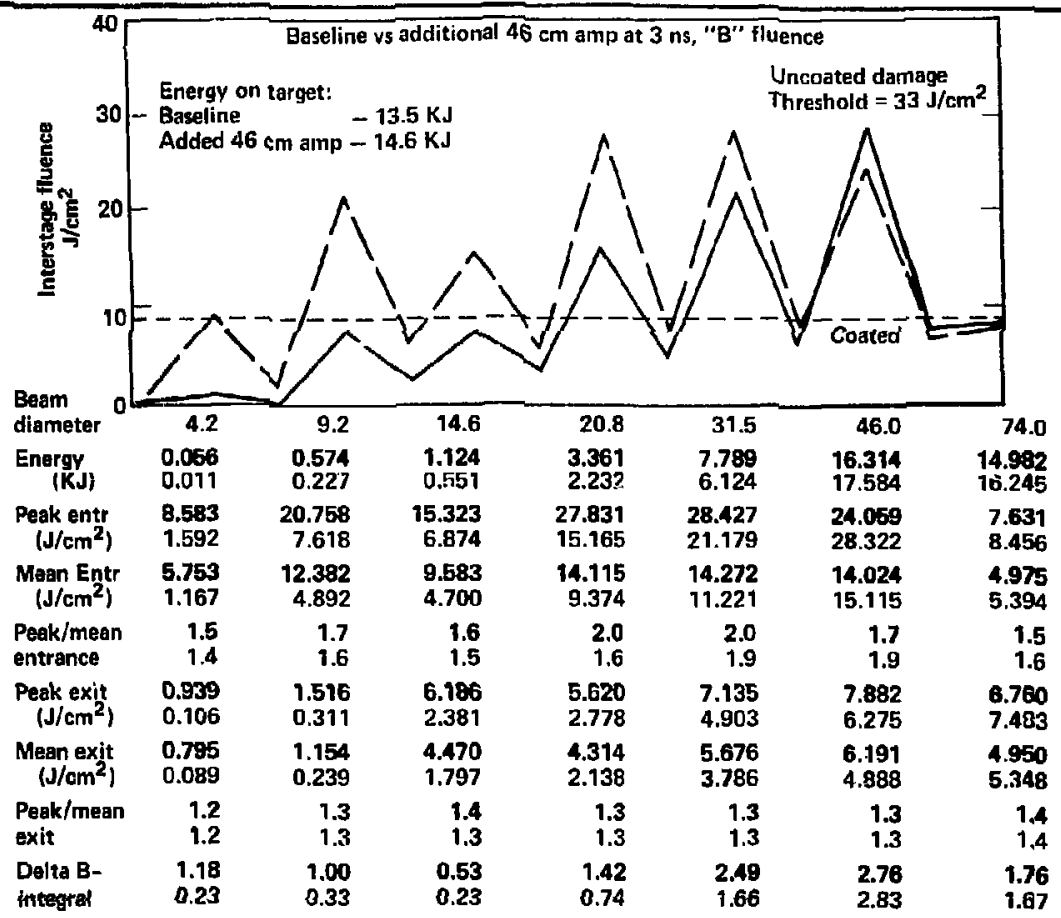

\section{2-32-1280-4504}

Baseline - dashed curve snadea aata
Adduicionial Adili - solid curve \& unshaded data

Fig. 9 


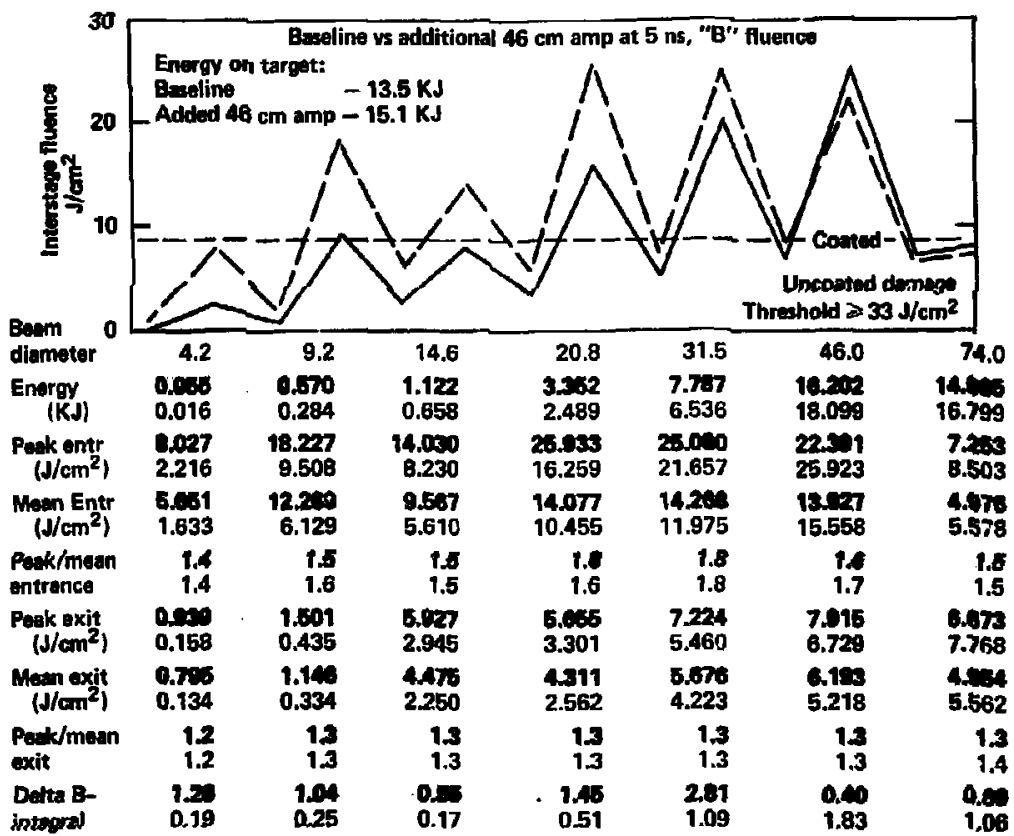

\section{2-32-1280-4505}

Baseline - dashed curve \& shaded data Additional Amp - solid curve \& unshaded data

Fig. 10 
$7.8 \mathrm{~cm}$ KDP TYPE II DOUBLING CRYSTALS WILL PROVIDE EFFICIENT SECOND HARMONIC ENERGY CONVERSION FOR THE NOVETTE LASER SYSTEM

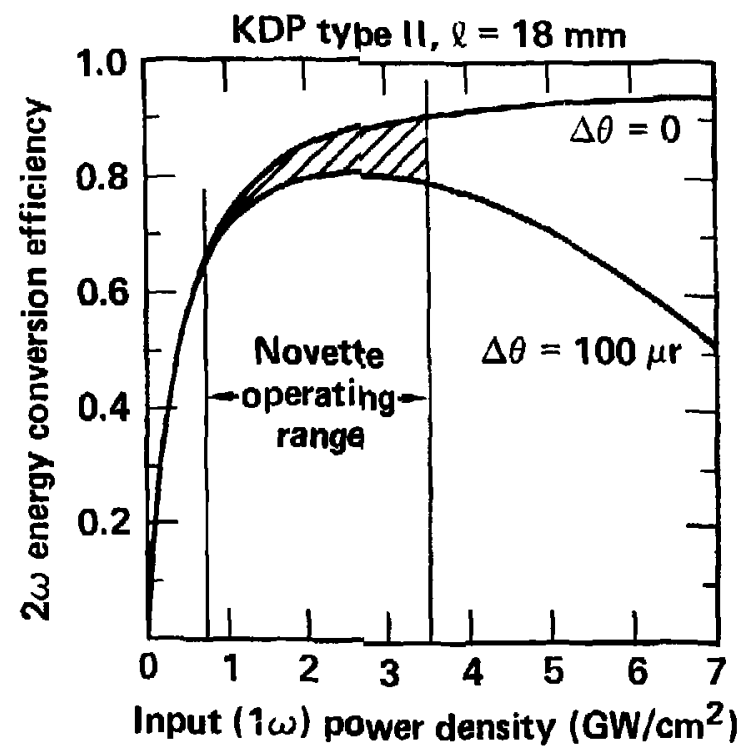

For Novette

$0.75 \leqslant I_{0} \leqslant 3.5 \mathrm{GW} / \mathrm{cm}^{2}$

02-32-1280-4479 


\section{NOVETTE BASELINE CHAIN PERFORMANCE,}

$1 \omega(1.05 \mu \mathrm{m})$ AND $2 \omega(0.53 \mu \mathrm{m})$, "A" AND "B" FLUENCES

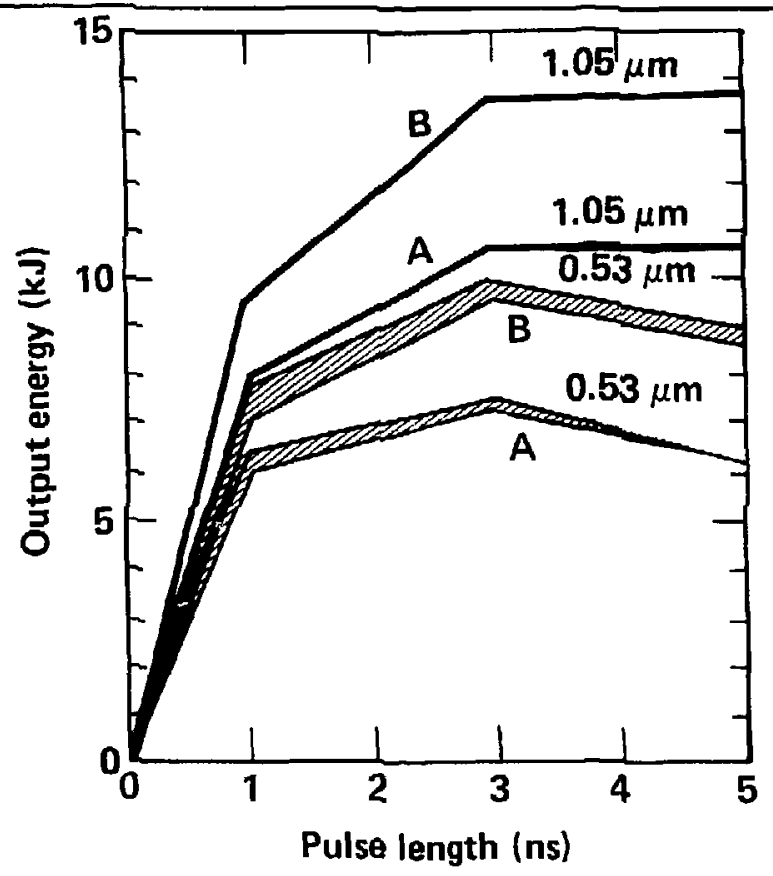

02-32-1280-4620 
NOVETTE CHAIN PERFORMANCE WITH ADDITIONAL $46 \mathrm{~cm}$ AMPLIFIER, $1 \omega(1.05 \mu \mathrm{m})$ and $2 \omega(0.53 \mu \mathrm{m})$, "B" FLUENCE

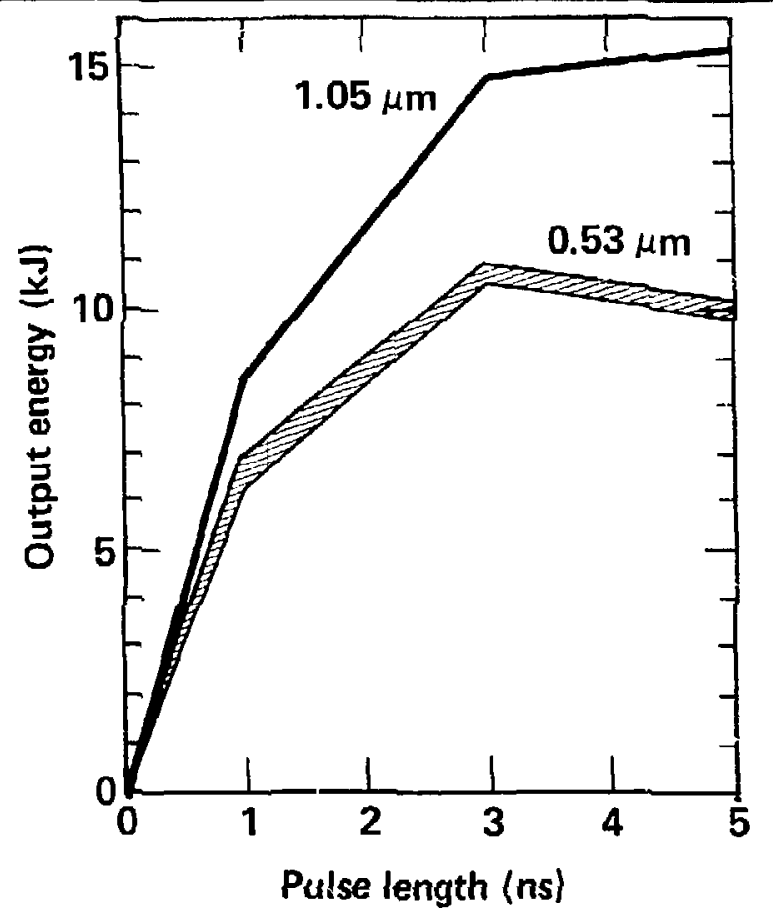

